\title{
ОБҐРУНТУВАННЯ ВПЛИВУ ЗУБНИХ ЕЛІКСИРІВ НА ОСНОВІ БІОФЛАВОНО ДІВ ЦИТРУСОВИХ НА СТАН АНТИОКСИДАНТНО-ПРООКСИДАНТНИХ СИСТЕМ ЯСЕН І СИРОВАТКИ КРОВІ ЩУРІВ ПРИ ЕКСПЕРИМЕНТАЛЬНОМУ ПАРОДОНТИТІ
}

\section{Львівський національний медичний університет імені Данила Галицького}

РЕЗЮМЕ. У досліді на 70 щурах з експериментальним перекисним пародонтитом вивчено вплив зубних еліксирів на основі біофлавоно дів цитрусових (апельсин, мандарин, грейпфрут) на стан антиоксидантно-прооксидантно системи в яснах і сироватці крові. Прооксидантну систему оцінювали за вмістом малонового діальдегіду (МДА), антиоксидантну - за активністю каталази. Встановлено, що моделювання пародонтиту призводить до збільшення вмісту МДА і зниження активності каталази. Використання еліксирів з цитрусовими нормалізує антиоксидантнопрооксидантний стан.

КЛЮЧОВІ СЛОВА: пародонтит, перекиси ліпідів, антиоксидантна система, цитрусові, зубні еліксири.

Вступ. Лікувальні властивості цитрусових відомі з давнини і вони широко використовуються в народній медицині [9]. Після відкриття вітаміну C і встановлення наявності його в плодах цитрусових, вважалося, що в механізмі лікувально-профілактично ді цитрусових лежить саме цей вітамін. Однак останнім часом, у зв'язку з вивченням широкого спектра біологічно ді біофлавоно дів (Р-вітамінних сполук), які в різній кількості знаходяться в шкірці цитрусових $[8,11,12]$, вважають, що лікувально-профілактичні властивості цитрусових обумовлені наявністю саме біофлавоно дів [4-6].

Метою дано роботи стало вивчення впливу зубних еліксирів на основі біофлавоно дів цитрусових на стан антиоксидантно-прооксидантних систем ясен і крові при моделюванні перекисного пародонтиту.

Матеріал і методи дослідження. У роботі було використано 70 щурів ліні Вістар стадного розведення обох статей у віці 1 місяць живою вагою 100 г. Експериментальний перекисний пародонтит відтворювали додаванням у корм переокислено олі із со з розрахунку $10 \mathrm{mл/Кг}$ корму [7]. Зубні еліксири готували з додаванням водно-спиртових (1:1) екстрактів з висушених та подрібнених шкірок цитрусових (апельсин, мандарин, грейпфрут). Екстракт готували шляхом настоювання подрібнених шкірок з водно-спиртовим розчином в співвідношенні 1:10 впродовж 3 діб. Зрошення порожнини рота щурів здійснювали 2 мл розведеного у 20 разів еліксиру щоденно впродовж 2 і 4 тижнів з першого дня відтворення пародонтиту.

Евтаназію щурів здійснювали під тіопенталовим наркозом через 2 і 4 тижні, збирали кров, 3 яко отримували сироватку і заморожували останню до проведення біохімічних досліджень. Виділяли ясна і готували з них гомогенати з розрахунку 20 мг/мл. У надосадовій рідині гомогенату ясен і в сироватці крові щурів визначали вміст малонового діальдегіду (МДА) [10] і активність каталази [2]. За співвідношенням активності каталази і концентраці МДА розраховували антиоксидантно-прооксидантний індекс (АПІ) [1].

Результати й обговорення. Одним із головних продуктів вільнорадикального окислення поліненасичених жирних кислот є МДА, який визначають за реакцією з тіобарбітуровою кислотою [10].

До складу антиоксидантно ферментно системи відносять такі ферменти, як глутатіонпероксидаза, глутатіонредуктаза, супероксиддисмутаза, каталаза та деякі інші. Встановлено, що зміни активності цих ферментів відбуваються синхронно, тому за рівнем одного з них можна скласти уявлення про характер реакці всіє антиоксидантно системи [3].

За результатами визначення вмісту МДА і активності каталази в яснах щурів під час розвитку перекисного пародонтиту, розвиток пародонтиту викликає збільшення в яснах рівня МДА в 1,5 раза. Застосування зубних еліксирів з екстрактами цитрусових приводить до суттєвого зниження рівня МДА. Активність каталази, навпаки, при пародонтиті знижується. Застосування зубних еліксирів з вмістом екстрактів цитрусових підвищує рівень каталази, причому найбільш ефективним виявився зубний еліксир «Грейпфрутовий» (табл. 1).

Більш виразно стан антиоксидантно та прооксидантно систем можна визначити через показник АПІ, який визначається за формулою:

$$
A \Pi I=\frac{A_{\text {каталази }} \cdot 100}{C_{\text {MДA }}} .
$$

Як видно з рисунка 1, показник АПІ при пародонтиті знижується майже в 2 рази. Застосування еліксирів з цитрусовими суттєво збільшує АПІ, особливо «Грейпфрутовий».

З результатів визначення вмісту МДА і активності каталази в сироватці крові з перекисним пародонтитом видно, що при пародонтиті вміст МДА збільшується в сироватці крові на 23-25\% 
Оеляди літератури, оригінальні дослідження, поеляд на проблему

Таблиця 1. Вплив зубного еліксиру з вмістом екстрактів цитрусових на антиоксидантно-прооксидантну систему ясен щурів при пародонтиті

\begin{tabular}{|c|c|c|c|c|c|}
\hline \multirow{2}{*}{$\begin{array}{l}\text { № } \\
\Pi / \Pi\end{array}$} & \multirow{2}{*}{ Групи } & \multicolumn{2}{|c|}{ МДА, ммоль/Кг } & \multicolumn{2}{|c|}{ Каталаза, мкат/кг } \\
\hline & & 2 тижні & 4 тижні & 2 тижні & 4 тижні \\
\hline 1 & Інтактні & \multicolumn{2}{|c|}{$25,9 \pm 3,0$} & \multicolumn{2}{|c|}{$8,0 \pm 0,4$} \\
\hline 2 & Пародонтит & $\begin{array}{c}38,2 \pm 3,8 \\
p<0,05\end{array}$ & $\begin{array}{c}35,9 \pm 3,2 \\
p<0,05\end{array}$ & $\begin{array}{l}5,8 \pm 0,6 \\
p<0,05\end{array}$ & $\begin{array}{l}6,4 \pm 0,4 \\
p<0,05\end{array}$ \\
\hline 3 & $\begin{array}{l}\text { Пародонтит+3/e } \\
\text { «Апельсиновий» }\end{array}$ & $\begin{array}{c}26,4 \pm 2,8 \\
\mathrm{p}>0,5 \\
\mathrm{p}_{1}<0,05\end{array}$ & $\begin{array}{c}27,2 \pm 3,5 \\
\mathrm{p}>0,5 \\
\mathrm{p}_{1}>0,05\end{array}$ & $\begin{array}{l}6,7 \pm 0,3 \\
p<0,05 \\
p_{1}>0,3\end{array}$ & $\begin{array}{c}7,5 \pm 0,5 \\
\mathrm{p}>0,3 \\
\mathrm{p}_{1}>0,05\end{array}$ \\
\hline 4 & $\begin{array}{l}\text { Пародонтит+3/e } \\
\text { «Мандариновий» }\end{array}$ & $\begin{array}{c}29,7 \pm 3,4 \\
\mathrm{p}>0,1 \\
\mathrm{p}_{1}>0,05\end{array}$ & $\begin{array}{c}21,8 \pm 2,2 \\
\mathrm{p}>0,05 \\
\mathrm{p}_{1}<0,05\end{array}$ & $\begin{array}{c}7,4 \pm 0,5 \\
\mathrm{p}>0,3 \\
\mathrm{p}_{1}>0,05\end{array}$ & $\begin{array}{c}8,0 \pm 0,2 \\
\mathrm{p}=1 \\
\mathrm{p}_{1}<0,05\end{array}$ \\
\hline 5 & $\begin{array}{l}\text { Пародонтит+3/e } \\
\text { «Грейпфрут» }\end{array}$ & $\begin{array}{c}24,9 \pm 4,5 \\
\mathrm{p}>0,6 \\
\mathrm{p}_{1}<0,05\end{array}$ & $\begin{array}{c}23,3 \pm 3,6 \\
\mathrm{p}>0,4 \\
\mathrm{p}_{1}<0,05\end{array}$ & $\begin{array}{l}8,8 \pm 0,6 \\
\mathrm{p}>0,05 \\
\mathrm{p}_{1}<0,01\end{array}$ & $\begin{array}{c}7,6 \pm 0,5 \\
\mathrm{p}>0,3 \\
\mathrm{p}_{1}>0,05\end{array}$ \\
\hline
\end{tabular}

Примітка: $p$ - показник достовірності в порівнянні з групою $1 ; p_{1}$ - показник достовірності в порівнянні з групою 2.

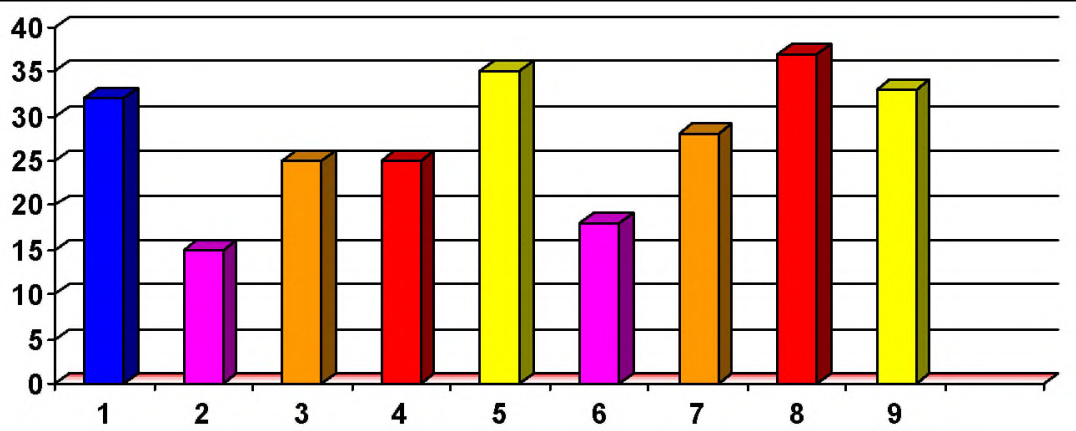

1 - інтактні;

2, 6 - пародонтит

(відповідно 2 і 4 тижні);

$3,7-$ пародонтит $+3 /$ e

«Апельсиновий»

(відповідно 2 і 4 тижні);

4, 8 - пародонтит + 3/е

«Мандариновий»

(відповідно 2 і 4 тижні);

5, 9 - пародонтит + 3/е

«Грейпфрутовий»

(відповідно 2 і 4 тижні).

Рис. 1. Вплив зубних еліксирів з вмістом екстрактів цитрусових на антиоксидантно-прооксидантний індекс (АПІ) ясен щурів з пародонтитом.

( $p<0,05)$, а активність каталази знижується, особливо в перший термін (2 тижні). Застосування даних зубних еліксирів в усіх випадках знижує рівень МДА в сироватці крові і, навпаки, підвищує знижений при пародонтиті рівень активності каталази, особливо в другий термін дослідження (табл. 2).

Таблиця 2. Вплив зубного еліксиру з вмістом екстрактів цитрусових на антиоксидантно-прооксидантну систему сироватки крові щурів при пародонтиті

\begin{tabular}{|c|c|c|c|c|c|}
\hline \multirow{2}{*}{ № ח/П } & \multirow{2}{*}{ Групи } & \multicolumn{2}{|c|}{ МДА, ммоль/кГ } & \multicolumn{2}{|c|}{ Каталаза, мкат/кг } \\
\hline & & 2 тижні & 4 тижні & 2 тижні & 4 тижні \\
\hline 1 & Інтактні & \multicolumn{2}{|c|}{$2,13 \pm 0,11$} & \multicolumn{2}{|c|}{$0,26 \pm 0,02$} \\
\hline 2 & Пародонтит & $\begin{array}{c}2,51 \pm 0,08 \\
\mathrm{p}<0,05\end{array}$ & $\begin{array}{c}2,66 \pm 0,13 \\
p<0,01\end{array}$ & $\begin{array}{c}0,17 \pm 0,02 \\
\mathbf{p}<0,01\end{array}$ & $\begin{array}{c}0,23 \pm 0,02 \\
p>0,5\end{array}$ \\
\hline 3 & $\begin{array}{l}\text { Пародонтит+3/e } \\
\text { «Апельсиновий» }\end{array}$ & $\begin{array}{c}2,10 \pm 0,20 \\
p>0,8 \\
p_{1}>0,05\end{array}$ & $\begin{array}{c}2,31 \pm 0,19 \\
p>0,2 \\
p_{1}>0,05\end{array}$ & $\begin{array}{c}0,22 \pm 0,01 \\
\mathrm{p}>0,05 \\
\mathrm{p}_{1}>0,05\end{array}$ & $\begin{array}{c}0,34 \pm 0,01 \\
\mathrm{p}<0,05 \\
\mathrm{p}_{\mathrm{l}}<0,01\end{array}$ \\
\hline 4 & $\begin{array}{l}\text { Пародонтит+3/е } \\
\text { «Мандариновий» }\end{array}$ & $\begin{array}{c}2,21 \pm 0,15 \\
\mathrm{p}>0,5 \\
\mathrm{p}_{1}>0,05\end{array}$ & $\begin{array}{c}2,34 \pm 0,15 \\
\mathrm{p}>0,05 \\
\mathrm{p}_{1}>0,1\end{array}$ & $\begin{array}{c}0,26 \pm 0,01 \\
\mathrm{p}=1 \\
\mathrm{p}_{1}<0,001\end{array}$ & $\begin{array}{c}0,33 \pm 0,03 \\
\mathrm{p}>0,05 \\
\mathrm{p}_{1}<0,05\end{array}$ \\
\hline 5 & $\begin{array}{l}\text { Пародонтит+3/e } \\
\text { «Грейпфрут» }\end{array}$ & $\begin{array}{c}2,20 \pm 0,18 \\
p>0,3 \\
p_{1}>0,05\end{array}$ & $\begin{array}{c}2,37 \pm 0,08 \\
p>0,1 \\
p_{1}>0,05\end{array}$ & $\begin{array}{c}0,22 \pm 0,01 \\
\mathbf{p}>0,05 \\
\mathbf{p}_{1}<0,05\end{array}$ & $\begin{array}{c}0,29 \pm 0,02 \\
p>0,1 \\
p_{1}<0,05\end{array}$ \\
\hline
\end{tabular}

Примітка: $\mathrm{p}$ - показник достовірності в порівнянні з групою $1 ; p_{1}$ - показник достовірності в порівнянні з групою 2

Більш показовим $\epsilon$ показник АПІ, який відображає співвідношення антиоксидантних і прооксидантних систем крові. Результати досліджень свідчать, що АПІ суттєво знижується при пародонтиті і значною мірою зростає при застосуванні еліксирів на основі біофлавоно дів цитрусових. 
Оеляди літератури, ориеінальні дослідження, поеляд на проблему

Отримані дані свідчать, що екстракти з шкірки цитрусових (апельсин, мандарин, грейпфрут) мають здатність регулювати стан антиоксидантнопрооксидантних систем організму, причому головним в механізмі хді на ці системи є здатність підвищувати рівень антиоксидантного захисту.

Результати дослідів показують, що захисний ефект екстрактів цитрусових виявляється не тільки локально, в місці х введення, а в усьому організмі. Тому можна вважати, що зубні еліксири, які місять біологічно активні речовини, можуть бути використані не тільки в лікуванні і профілактиці стоматологічних захворювань, але й при загальносоматичній патологі.

\section{ЛІТЕРАТУРА}

1. Антиоксидантно-прооксидантний індекс сироватки крові щурів з експериментальним стоматитом і його корекція зубним еліксирами / А. П. Левицький, В. М. Почтар, О. А. Макаренко, Л. І. Гридіна // Одеський мед. журн. 2006. № 1. - С. 22-25.

2.Гирин С. В. Модификация метода определения активности каталазы в биохимических субстратах // Лабор. Диагностика. - 1999. - № 4. - С. 45-46.

3. Гирин С. В. Перекисное окисление липидов и состояние антиоксидантной системы организма при индуцированом мутационном процессе, вызванном острим действием сульфата никеля / С. В. Гирин // Лаб. диагностика. - 1999. - № 1. - С. 13-15.

4. Доркина Е. Г. Изучение гепатозащитного действия природных флавоноидных соединений / Е. Г. Доркина // Эксперим. и клин, фармакология. - 2004. - Т. 67, № 6. C. 41-44.

5. Зубачик В. М. Вплив біофлавоно дів апельсина на стан тканин порожнини рота за умов експериментального пародонтиту / В. М. Зубачик, І. П. Двуліт, А. П. Левицький // Новини стоматологі . - 2006. - № 4. - С. 38-40.

6. Кариеспрофилактическое, пародонтопротекторное и антиоксидантное действие зубных эликсиров «Апельсиновый» и «Мятный» при экспериментальном стоматите /
Висновки. 1. При експериментальному перекисному пародонтиті в яснах і сироватці крові збільшується концентрація МДА і знижується активність каталази.

2. Зрошування слизово оболонки порожнини рота зубними еліксирами на основі біофлавоно дів цитрусових нормалізує стан антиоксидантнопрооксидантних систем, більшою мірою в яснах.

3. Суттєвих розбіжностей в характері ді екстрактів різних цитрусових не виявлено.

Застосування зубних еліксирів з вмістом біологічно активних речовин цитрусових може бути корисним не тільки при стоматологічній патологі, але й при загальносоматичних захворюваннях.

В. Я. Скиба, Е. П. Пустовойт, В. Н. Почтарь, Л. Н. Россаханова // Вісн. стоматологі . - 2006. - № 2. - С. 8-12.

7. Козлянина Н. П. Физиологическая антиоксидантная система десны и кости альвеолярного отростка в норме и при патологии : автореф. дисс. канд. биол. наук. - К., 1990. - 17 с.

8. Левицкий А. П. Биофлавоноиды как регуляторы физиологических функций // Вісн. стоматологі . - 2001. № 1. - С. 71-76.

9. Лимон и другие цитрусовые / Сост. Л. Г. Лебедева.- М. : ООО изд-во «Астрель»; ООО изд-во «АСТ». 2004. - 92 c.

10. Стальная И. Д. Метод определения малонового диальдегида с помощью тиобарбитуровой кислоты / И. Д. Стальная, Т. Г. Гаришвили // Современные методы в биохимии. - М. : Медицина, 1997. - С. 66-68.

11. Тутельян В. А. Флавоноиды: содержание в пищевых продуктах, уровень потребления, биодоступность / В. А. Тутельян, А. Х. Батурин, Э. А. Мартинчик // Вопр. питания. - 2004. - Т. 73, № 6. - С. 43-48.

12. Middleton $E$. The effect of plant flavonoides on mamalian cells: Implications for inflammation, heart diseases and cancer / E. Middleton, C. Kandaswami, T. Theoharides // Pharmacological Review. - 200. - Vol. 52, № 4. - P. 673-701.

\section{JUSTIFICATION OF THE INFLUENCE OF DENTIFRICE WATERS CONTAINING BIOFLAVONOIDS OF CITRUS UPON THE STATE OF ANTIOXIDANT-PROOXIDANT SYSTEMS OF GUMS AND BLOOD SERUM OF RATS AT EXPERIMENTAL PERIODONTITIS}

\section{Lviv National Me dical University by Danylo Halytsky}

이. P. Dvulit

SUMMARY. In the investigations with 70 rats with experimental peroxide periodontitis the influence of dentifrice waters containing bioflavonoides citrus (orange, mandarin, grapefruit) upon the state of antioxidant-prooxidant systems in gums and blood serum were studied.

The ptooxidant system was estimated according to the contents of malonic dialdehyde (MDA), the antioxidant one - to the activity of catalase. It was determined that the simulation of periodontitis results in the growth in contents og MDA and reduction of activity of catalase. The use of dentifrice waters with citrus normalizes antioxidant-prooxidant state.

KEYWORDS: periodontitis, lipids peroxides, antioxidant system, citrus, dentifrice waters. 